\title{
PEMANFAATAN SERAT SISAL (agave sisalana L.) DAN LIMBAH PLASTIK PET UNTUK PEMBUATAN BATA RINGAN CLC (CELLULAR LIGHTWEIGHT CONCRETE)
}

\author{
Fauzi Widyawati ${ }^{\star *}$, Tsabit Abdi Haqqi ${ }^{2}$ \\ 1,2Program Studi Teknik Metalurgi Fakultas Teknik Universitas Teknologi Sumbawa \\ *Corresponding Author email: fauzi.widyawati@uts.ac.id
}

\begin{tabular}{|c|c|}
\hline & Abstrak \\
\hline $\begin{array}{l}\text { Diterima } \\
\text { Bulan Januari } \\
2020\end{array}$ & $\begin{array}{l}\text { Beberapa waktu lalu di wilayah Nusa Tenggara Barat (NTB) mengalami guncangan } \\
\text { gempa yang sangat menggemparkan masyarakat sehingga banyak bangunan yang hancur } \\
\text { dan rata dengan tanah. Sementara saat ini pemanfaatan limbah plastik sedang menjadi } \\
\text { perhatian masyarakat maupun pemerintah terutama diwilayah NTB. Sehingga latar } \\
\text { belakang inilah yang menjadi dasar penelitian untuk membuat bata ringan tahan gempa }\end{array}$ \\
\hline Diterbitkan & dengan memanfaatkan limbah plastik PET untuk menggantikan agregat kasar sebagai \\
\hline Bulan Februari & campuran dan memanfaatkan serat sisal sebagai penguat (reinforce) untuk meningkatkan \\
\hline 2020 & $\begin{array}{l}\text { kekuatan bata ringan. Tujuan dilakukannya penelitian ini adalah untuk mengetahui cara } \\
\text { pembuatan bata ringan jenis CLC (Cellular Lightweight Concrete) dengan memanfaatkan }\end{array}$ \\
\hline & limbah plastik PET dan serat sisal, untuk mengetahui pengaruh penambahan plastik PET \\
\hline Komposit, PET, & $\begin{array}{l}\text { maupun serat sisal terhadap sifat mekanik bata ringan, serta untuk mengetahui komposisi } \\
\text { optimum dari penambahan plastik PET dan serat sisal pada pembuatan bata ringan CLC. }\end{array}$ \\
\hline serat sisal, bata & Penggunaan plastik PET dan serat sisal menghasilkan bata dengan massa jenis rata-rata \\
\hline ringan & $1.830,419 \mathrm{~kg} / \mathrm{m}^{3}$ untuk sampel variasi $1: 1,1.880 \mathrm{~kg} / \mathrm{m} 3$ untuk sampel variasi $4: 1$, dan \\
\hline & $1.887,654 \mathrm{~kg} / \mathrm{m}^{3}$ untuk sampel variasi $1: 4$. Kekuatan tekan maksimum dicapai pada \\
\hline & ampel variasi 1:4 yaitu sampel dengan penambahan serat sisal 4 kali lebih banyak dari \\
\hline & plastik PET. Berdasarkan hasil pengukuran massa jenis bata, hanya sampel variasi $1: 1$ \\
\hline & yang memenuhi standar SNI $2847-2013$ bata ringan $\left(1.140-1.840 \mathrm{~kg} / \mathrm{m}^{3}\right)$. Penambahan \\
\hline & serat sisal yang lebih banyak 4 kali dari plastik PET (sampel variasi 1:4) memiliki nilai \\
\hline & kekuatan tekan paling tinggi yaitu $8,5 \mathrm{MPa}$ dan masuk dalam kategori bata ringan mutu I. \\
\hline
\end{tabular}

\section{PENDAHULUAN}

Teknologi bata ringan saat ini sedang berkembang pesat terutama setelah banyaknya terjadi gempa di beberapa tempat Indonesia terutama gempa yang pernah mengguncang daerah Lombok, Nusa Tenggara Barat. Pendekatan rancang bangun untuk bangunan tahan gempa harus didasarkan kekuatan lateral, mampu bentuk dan keuletan struktur dengan batas tertentu tetapi tidak mudah runtuh. Faktor utama untuk membuat bangunan tahan gempa yaitu desain bangunan yang aman dan konstruksi dengan material yang berkualitas(Lumingkewas, 2018). Bata ringan jenis CLC (Cellular Lightweight Concrete) juga bisa disebut sebagai beton ringan aerasi, yaitu beton yang bahan baku pembuatannya terdiri dari pasir silika, kapur, semen, air, ditambah dengan bahan pengembang yang kemudian dirawat dengan tekanan uap air. bahan pengembang tersebut akan mengembang selama proses pengerasan tanpa menyebabkan reaksi kimia dan akan berfungsi sebagai pengisi ruang bata sehingga bata menjadi ringan(Winarno dkk., 2013).

Sekarang ini, banyak penelitian mengarah pada pemanfaatan sampah dan limbah di Indonesia karena sampah dan limbah tersebut sudah sejak lama menjadi permasalahan nasional. Sampah plastik di Indonesia mencapai 64 juta ton/tahun di mana sebanyak 3,2 juta ton merupakan sampah plastik yang dibuang ke laut. Pada provisi Nusa tenggara barat khususnya kota Mataram tercatat data Volume Sampah Terangkut per hari menurut Jenis Sampah anorganik yang direkam oleh badan statistik lingkungan hidup Indonesia pada tahun 2016-2017 sebesar 78,65 dan 112 ton(Safitri dkk., 2018). Salah satu langkah pemanfaatan kembali sampah plastik yaitu membuat salah satu komposit antara material keramik dan material polimer yaitu bata ringan yang green sustainable atau bisa dikategorikan bata ringan jenis CLC. Bata ringan ini memanfaatkan sampah plastik jenis PET (Polyethylene Terephthalate) yang didapat dari kemasan botol minuman sekali pakai.

Penambahan serat (agave sisalana L) pada bata ringan difungsikan untuk meningkatkan kuat tekan bata dan juga mampu mengurangi densitas bata sehingga kedua bahan tersebut untuk mendapatkan sifat mekanik bata. Penjelasan di atas mengenai penambahan limbah plastik PET dan serat sisal untuk pembuatan komposit bata ringan menjadi latar belakang penelitian ini dilaksanakan.

\section{LANDASAN TEORI}

\section{Plastik PET (Polyethylene Terephthalate)}

PET (Polyethylene Terephthalate) merupakan plastik jenis termoplast. Plastik ini memiliki karakteristik jernih, kuat, kaku, tidak 
beracun, dan daya serap air rendah. PET digunakan sebagai botol plastik untuk menyimpan cairan seperti minuman bersoda, air mineral, jus, minyak. PET bisa didaur ulang menjadi karpet, jaket, bahan kain/tekstil, dan tempat penyimpanan makanan(Mohana Priya dkk., 2018). Tabel 1 di bawah ini menunjukkan propertis dari plastik PET.

Limbah plastik PET ini digunakan sebagai agregat kasar menggantikan bahan agregat kasar kerikil yang biasanya digunakan untuk campuran beton(Alfiandi dan Nursyamsi, n.d.).

Tabel 1. Propertis plastik PET

(Mohana Priya dkk., 2018)

\begin{tabular}{cc}
\hline Property & Result \\
\hline Chenical formula & $\left(\mathrm{C}_{10} \mathrm{H}_{8} \mathrm{O}_{4}\right)$ \\
\hline Density & $1.38 \mathrm{~g} / \mathrm{cm}^{3}\left(20^{\circ} \mathrm{C}\right)$ \\
\hline Melting point & $>250^{\circ} \mathrm{C}, 260^{\circ} \mathrm{C}$ \\
\hline Boiling point & $>350^{\circ} \mathrm{C}($ decomposes $)$ \\
\hline
\end{tabular}

\section{Serat Sisal (agave sisalana L.)}

Serat sisal merupakan salah satu bahan penguat (reinforce material) komposit yang berasal dari serat alam non kayu dan bahan bakunya banyak ketersedian di dunia ini. Sebagai bahan penguat komposit, serat sisal memiliki kelebihan antara lain memiliki sifat mekanik yang baik, serat dapat terbiodegradasi dengan lingkungan, densitas rendah, mudah didapat, dan harganya yang murah(Kusumastuti, 2009). Tumbuhan sisal (agave sisalana L.) banyak tumbuh di daerah tropis dan subtropis seperti di Indonesia terdapat di Pulau Madura, Malang Selatan, Jember dan Blitar Selatan, serta Kabupaten Sumbawa barat. Kabupaten Sumbawa barat memproduksi 92 ton pelepah tanaman sisal per tahun dan diolah menjadi serat rendemen mencapai 5\%(Basuki dan Verona, 2017).

Serat sisal memiliki komposisi selulosa $78 \%$, hemiselulosa 19\%, lignin 8\%, dll. Manfaat selulosa yang tinggi pada sisal bersifat kuat, berkristal molekul tanpa percabangan(Suryanto, 2016).

\section{MATODE PENELITIAN}

\section{Material}

Dalam pembuatan komposit bata ringan, ada beberapa bahan yang digunakan sebagai komponen komposit dan juga komponen pembuatan bata ringan. Komponen komposit utamanya harus ada matrix dan reinforce. Limbah plastik yang digunakan sebagai matrix penyusun komposit bata ringan diambil dari botol plastik jenis PET yaitu botol plastik kemasan air mineral yang sudah dicacah dengan ukuran cacahan 1-2 cm dan reinforce yang digunakan adalah serat sisal dengan arah serat pendek (discontinue). Serat sisal didapatkan dari PT. PULAU SUMBAWA AGUNG Kecamatan Poto Tano, Kabupaten Sumbawa Barat - Nusa Tenggara Barat.
Selain dari komponen penyusun komposit, ada pula bahan pembuat bata ringan yaitu semen jenis PCC (Portland Composite Cement) type I yaitu merek Tiga Roda ukuran kemasan $50 \mathrm{~kg}$, pasir sungai Samapuin Kabupaten Sumbawa, dengan spesifikasi gradasinya yaitu yang lolos ayakan 4.7 mm sesuai SNI 02-6820-2002, foam agent produksi PT. PERKASAJAYA-TEGAL yang berfungsi untuk menambah volume bata ringan tanpa menambah berat bata ringan tersebut, dan juga penambahan air PDAM Semongkat yang ada di lokasi Laboratorium PT. BRL.

\section{Karakterisasi}

Standar penelitian mengacu pada standar SNI untuk pengujian bata ringan dan ASTM sebagai acuan spesifikasi bahan penyusun bata ringan. Mix design mengacu pada massa jenis bata ringan berdasarkan standar SNI 2847-2013 yaitu massa jenisnya antara $1.140 \mathrm{~kg} / \mathrm{m}^{3}$ sampai dengan 1.840 $\mathrm{kg} / \mathrm{m}^{3}$. Penelitian ini dilakukan dengan membandingkan bata ringan normal dengan bata ringan berbasis serat sisal dan plastik PET. Sampel bata ringan berbentuk kubus berukuran $15 \mathrm{~cm} \mathrm{x}$ $15 \mathrm{~cm}$ x $15 \mathrm{~cm}$ sebanyak 12 sampel keseluruhan.

Pada penelitian ini, dibuat 4 variasi sampel yang dirancang dan dihitung komposisi campuran untuk bata ringan. Perhitungan masing-masing campuran bata ringan berdasarkan massa jenis total bahan yang akan digunakan untuk mencetak satu benda uji. Perhitungan berat satu bata yang akan digunakan ada di bawah ini.

Target massa jenis campuran $=1.925 \mathrm{~kg} / \mathrm{m}^{3}$

Volume 1 buah bata

$=\mathrm{p} \times 1 \times \mathrm{t}$.

$=0,15 \mathrm{~m} \times 0,15 \mathrm{~m} \times 0,15 \mathrm{~m}$

$=0,003375 \mathrm{~m}^{3}$

Massa 1 buah kubus

$=$ Berat Jenis $\mathrm{x}$ Volume.

$=1.925 \mathrm{~kg} / \mathrm{m}^{3} \times 0,003375 \mathrm{~m}^{3}$

$=6,496875 \mathrm{~kg}=6,5 \mathrm{~kg}$

$=6.500$ gram

Variasi komposisi sampel uji yang digunakan untuk bata ringan pada penelitian ini secara detai ada pada tabel 2. Sampel terdiri dari sampel uji normal dan sampel uji dengan variasi rasio cacahan botol plastik PET dan serat sisal dengan variasi rasio pembuatannya seperti pada tabel 2. Sampel normal adalah sampel yang tidak ditambahkan cacahan botol plastik, sampel 1:1 adalah sampel dengan rasio penambahan cacahan plastik dan serat sisal 1:1, sampel 1:4 adalah sampel dengan rasio penambahan cacahan plastik dan serat sisal 4:1, dan sampel 4:1 adalah sampel dengan rasio penambahan serat lebih banyak dibandingkan cacahan plastik 4 kali lipat berat plastik. 
Tabel 2. Mix design komposisi bata ringan

\begin{tabular}{c|ccccccc}
\hline $\begin{array}{c}\text { Variasi } \\
\text { Sampel }\end{array}$ & Plastik PET (gr) & $\begin{array}{c}\text { Serat } \\
\text { Sisal (gr) }\end{array}$ & $\begin{array}{c}\text { Foam } \\
\text { Agent }(\mathrm{gr})\end{array}$ & $\begin{array}{c}\text { Semen } \\
(\mathrm{gr})\end{array}$ & $\begin{array}{c}\text { Pasir } \\
(\mathrm{gr})\end{array}$ & $\begin{array}{c}\text { Air } \\
(\mathrm{gr})\end{array}$ & FAS \\
\hline Normal & 0 & 0 & 7,11 & $1.778,39$ & $4.001,37$ & 713,13 \\
$\mathbf{1}: \mathbf{1}$ & 50 & 50 & 7 & $1.751,03$ & $3.939,81$ & 702,16 & 0,4 \\
$\mathbf{1}: \mathbf{4}$ & 20 & 80 & 7 & $1.751,03$ & $3.939,81$ & 702,16 & 702,16 \\
$\mathbf{4}: \mathbf{1}$ & 80 & 20 & 7 & $1.751,03$ & $3.939,81$ & \\
\hline
\end{tabular}

Sampel bata ringan yang sudah dicetak kemudian dikeringkan selama 24 jam atau sampai kering, lalu dilakukan perawatan bata dengan cara direndam dalam air selama 21 hari hingga waktu pengujian kuat tekan dilakukan. Pengujian kuat tekan dilakukan menggunakan mesin tekan (Universal Testing Machine) dengan kapasitas $2000 \mathrm{kN}$. Mekanisme uji tekan bata ringan yaitu sampel ditekan sampai nilai kuat tekan mengalami penurunan atau dengan kata lain sudah mencapai kuat tekan maksimum dan bata pun patah.

\section{HASIL DAN PEMBAHASAN}

\section{Penghitungan massa jenis sampel bata}

Langkah awal pengujian yaitu penghitungan massa jenis sampel yang dibuat. Pengujian ini dilakukan untuk mengukur kepadatan dari bata yang dibuat. Perhitungan massa jenis sampel bata ringan mengikuti rumus yang sudah ada pada SNI 2847-2013 sebagaimana ditetapkan oleh ASTM C567 yaitu perbandingan antara massa bata dan volume bata. Hasil penghitungan massa jenis sampel bata ringan harus mengikuti standar SNI 2847-2013 yaitu antara 1.140 sampai $1.840 \mathrm{~kg} / \mathrm{m}^{3}$. Adapun hasil penelitian yang didapatkan pada tabel 3 untuk rata-rata massa jenis per sampel dan gambar 1 untuk grafiknya.

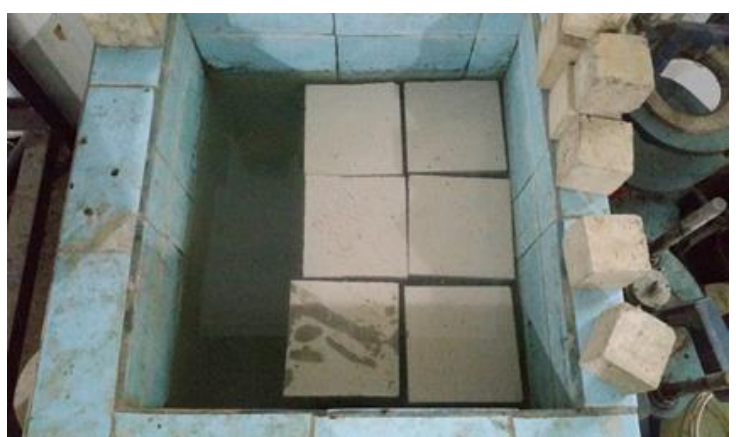

Gambar 1. Proses perendaman komposit bata

Gambar 1 menunjukkan proses perendaman sampel komposit bata yang sudah dicetak dan dikeringkan. Penghitungan massa jenis bata ringan dilakukan dari bata hasil perendaman selama 21 hari pada sampel normal dan sampel yang sudah divariasikan komposisi batanya.
Pada diagram di gambar 2, secara umum sampel bata ringan yang dicampur plastik PET dan serat sisal memiliki massa jenis yang lebih ringan dari bata normal. Bata ringan yang ditambahkan limbah plastik PET dan serat sisal dengan perbandingan 1:1 memiliki massa jenis lebih ringan 4.3\% dari bata normal. Penurunan massa jenis pada sampel variasi 1:1 membuktikan bahwa massa jenis plastik PET dan serat sisal yang digunakan dalam campuran bata lebih ringan daripada pasir yang digunakan pada bata normal. Perlu diketahui bahwa massa jenis pasir sungai Samapuin sebesar 1,256 $\mathrm{gr} / \mathrm{m}^{3}$, massa jenis cacahan botol plastik PET sebesar $0,150 \mathrm{gr} / \mathrm{m} 3$, dan massa jenis serat sisal $0,074 \mathrm{gr} / \mathrm{m}^{3}$.

Tabel 3 Data Hasil Pengukuran Massa Jenis Sampel Bata

\begin{tabular}{c|c|cccc}
\hline $\begin{array}{c}\text { No } \\
\text { sampel }\end{array}$ & Hari & \multicolumn{4}{|c}{ Massa Jenis Sampel $\left(\mathrm{kg} / \mathrm{M}^{3}\right)$} \\
& ke- & Normal & $1: 1$ & $4: 1$ & $1: 4$ \\
\hline $\mathbf{1}$ & & $1.917,93$ & $1.831,70$ & $1.884,15$ & $1.881,33$ \\
$\mathbf{2}$ & \multirow{2}{*}{21} & 1.904 & $1.830,37$ & $1.882,82$ & $1.889,48$ \\
$\mathbf{3}$ & & $1.916,89$ & $1.829,19$ & $1.873,04$ & $1.892,15$ \\
\multicolumn{1}{l}{$\frac{\bar{X}}{}$} & & $1.912,938$ & $1.830,419$ & 1.880 & $1.887,654$
\end{tabular}

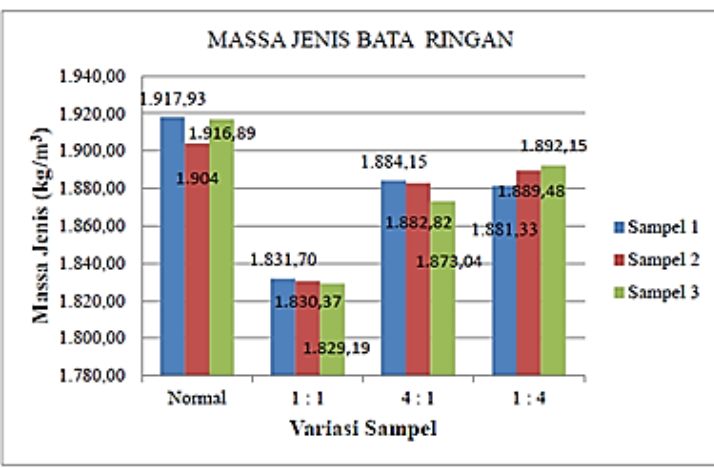

Gambar 2. Massa jenis sampel bata

Penambahan komposisi plastik PET (sampel 4:1) dan serat sisal (sampel 1:4) meningkatkan massa jenis bata tersebut tetapi masih di bawah massa jenis bata normal. Pada sampel 1:4 memiliki massa jenis paling tinggi di antara variasi bata lainnya. Hal ini terjadi karena saat pengukuran massa jenis bata dilakukan setelah proses perawatan selama 21 hari. Serat sisal merupakan absorben yang baik dalam bata sebab nilai absorpsi serat sisal sebesar 12,16\%(Artha Sastra dkk., 2013) sehingga 
mampu menyerap air saat perawatan dan meningkatkan massa jenis bata tersebut.

Berdasarkan standar SNI 03-2847-2013, bata dikategorikan sebagai bata ringan jika memiliki massa jenis antara $1.140 \mathrm{~kg} / \mathrm{m}^{3}$ sampai dengan 1.840 $\mathrm{kg} / \mathrm{m}^{3}$. Walaupun belum ada sampel bata yang masuk dalam kategori bata ringan, namun massa jenis sampel variasi 4:1 dan 1:4 sudah mendekati dalam kategori tersebut. Sampel variasi 1:1 dengan massa jenis 1.830,419 sudah masuk dalam kategori bata ringan.

\section{Data pengujian tekan bata ringan}

Pengujian kuat tekan sampel bata ringan dilakukan setelah proses perawatan selama 21 hari. Sampel diuji dengan mesin uji tekan dengan kapasitas beban $2000 \mathrm{kN}$ dan luas permukaan penekanan sampel adalah $0,0225 \mathrm{~m}^{2}$ sebanyak 12 sampel. Pada gambar 3 di bawah ini merupakan data hasil uji tekan bata.

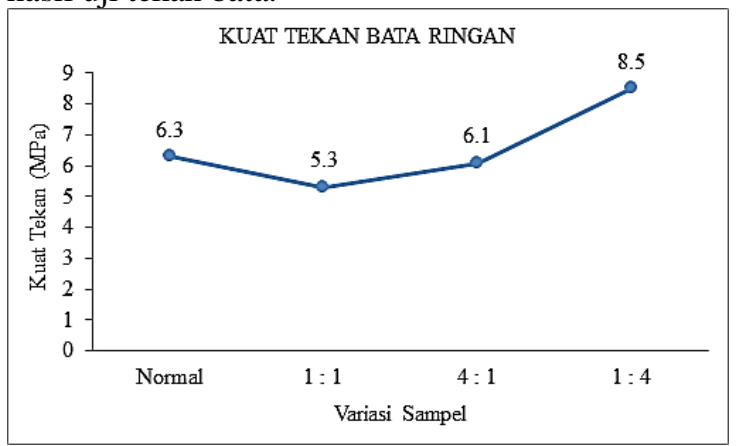

Gambar 3. Data kekuatan tekan sampel bata

Berdasarkan grafik di atas terlihat kekuatan tekan bata normal 6,3 $\mathrm{MPa}$ dan sampel variasi 1:1 sebesar 5,3 MPa. Kekuatan tekan sampel tersebut mengalami penurunan dikarenakan komposisi antara serat sisal dan plastik PET belum mencukupi untuk menahan beban tekan saat pengujian. Sampel 4:1 dan sampel 1:4 mengalami peningkatan kekuatan tekan seiring meningkatnya jumlah plastik PET maupun serat sisal. Peningkatan kekuatan tekan antara sampel 1:1 dan sampel 4:1 sebesar 13\% dikarenakan jumlah plastik PET yang banyak dan permukaan plastik PET licin sehingga saat diuji tekan mempermudah pergeseran antara semen dan permukaan plastik dan tidak mampu menahan beban tekan dengan optimal.

Perbandingan nilai kekuatan tekan antara sampel 1:1 dan sampel 1:4 mengalami peningkatan secara signifikan yaitu sebesar $37,6 \%$. Hal ini terjadi karena komposisi serat sisal sebagai penguat pada bata berfungsi dengan baik. serat sisal pada komposisi bata 4 kali lebih banyak berfungsi untuk menguatkan bata karena permukaan serat sisal yang kasar dan sifat mekanik serat sisal yang memiliki kekuatan tarik 530-630 MPa(Suryanto, 2016) mampu menambah kekuatan tekan bata. Serat sisal dalam konstruksi bangunan berfungsi sebagai penguat mikro yang mampu meminimalkan risiko keretakan bata ringan saat terjadi guncangan atau gempa.

Berdasarkan hasil pengukuran massa jenis dan pengujian kuat tekan belum ada bata ringan, hanya ada satu bata variasi 1:1 yang masuk kategori bata ringan namun mutu bata ringan tersebut masih belum maksimal dalam kuat tekan. Bata variasi 1:4 memiliki kuat tarik paling baik di antara sampel lainnya dan masuk kategori bata mutu I untuk pemakaian dinding yang dibebani dan tidak terlindungi namun massa jenisnya melebihi standar SNI. Hal ini terjadi karena pengukuran massa jenis bata tersebut diukur dalam keadaan basah setelah proses perawatan. Alangkah lebih baiknya pengukuran massa jenis bata dilakukan saat bata dalam keadaan kering sehingga akan menghasilkan data yang lebih akurat

\section{KESIMPULAN}

Berdasarkan hasil analisa dan pembahasan pada penelitian ini, maka dapat ditarik kesimpulan sebagai berikut :

1. Penggunaan limbah plastik PET dapat menjadi penambah agregat kasar dalam pembuatan bata ringan namun penambahan limbah plastik PET belum maksimal untuk dapat menahan kekuatan tekan bata ringan sedangkan penambahan serat sisal memberikan pengaruh yang baik untuk kekuatan bata sehingga bata tidak mudah pecah saat pengujian tekan.

2. Bata yang ditambahkan limbah plastik PET dan serat sisal memiliki massa jenis rata-rata 1830,419 $\mathrm{kg} / \mathrm{m}^{3}$ untuk sampel bata 1:1 yang termasuk dalam kategori bata ringan (standar SNI 2847-2013 yaitu $\left.1.140-1.840 \mathrm{~kg} / \mathrm{m}^{3}\right)$.

3. Bata dengan penambahan serat sisal paling banyak yang mampu meningkatkan kekuatan tekan sebesar 26\% dari bata normal yaitu bata sampel 1:4 dengan nilai kekuatan tekan 8.5 MPa.

4. Bata sampel 1:4 memang belum memenuhi standar SNI berdasarkan massa jenisnya, namun dari nilai kekuatan tekan hanya sampel 1:4 yang tergolong dalam kategori mutu I dengan kuat tekan minimum 6.5 MPa.

Berdasarkan massa jenis yang dihasilkan maka bata tersebut belum bisa dikategorikan sebagai bata ringan tetapi masih bisa dilakukan penghitungan massa jenis yang lebih akurat untuk memenuhi standar bata ringan berdasarkan SNI 2847-2013.

\section{REFERENSI}

Alfiandi, D. G., dan Nursyamsi (n.d.): Pengaruh Penggunaan Limbah Plastik Pet Sebagai Agregat Kasar Pada Beton Ringan Struktural.

Artha Sastra, I. P. K., Sari, N. H., dan Sujita, S. (2013): Analisis Uji Penyerapan Air Dan Struktur Mikro Komposit Laminate Hybrid Serat Sisal Dan Batang Pisang Dengan 
Matrik Epoxy, Dinamika Teknik Mesin, 3(1), 41-49, https://doi.org/10.29303/d.v3i1.87.

Basuki, T., dan Verona, L. (2017): MANFAAT SERAT SISAL (Agave sisalana L.) DAN BAMBU (Bambusoideae) UNTUK MEMENUHI KEBUTUHAN MASYARAKAT MODERN, 11 (November).

Kusumastuti, A. (2009): Aplikasi Serat Sisal sebagai Komposit Polimer, 1(1), 27-32.

Lumingkewas, R. H. (2018): Beton nano komposit serat alam sebagai bahan konstruksi infrastruktur tahan gempa, 251-257.

Mohana Priya, N., Nirmala, M., dan Dhanalakshmi, G. (2018): Replacement of Bricks With
Plastic Bottles in Construction, International Research Journal of Engineering and Technology, Volume: 05(May), 1551-1555, diambil dari www.irjet.net.

Safitri, pramudya ajeng, Purba, winda sartika, dan Zulkifli, M. (2018): Statistik lingkungan hidup indonesia.

Suryanto, H. (2016): Review Serat Alam : Komposisi, Struktur dan Sifat Mekanis, ResearchGate, (Octoberv), 1-14.

Winarno, S., Basyarah, M. G., dan Noor, I. (2013): PEMBUATAN BATA RINGAN MENGGUNAKAN LIMBAH PENGGERGAJIAN BATU ANDESIT, 978979-98438-8-3, 978-979. 